\title{
Functional significance of the sex chromosomes during spermatogenesis
}

\author{
Yueh-Chiang $\mathrm{Hu}^{1}$ and Satoshi H Namekawa ${ }^{1,2}$ \\ ${ }^{1}$ Division of Developmental Biology and ${ }^{2}$ Division of Reproductive Sciences, Cincinnati Children's Hospital \\ Medical Center, Cincinnati, Ohio 45229, USA
}

Correspondence should be addressed to Y-C Hu; Email: yueh-chiang.hu@cchmc.org or to S H Namekawa; Email: satoshi.namekawa@cchmc.org

\begin{abstract}
Mammalian sex chromosomes arose from an ordinary pair of autosomes. Over hundreds of millions of years, they have evolved into highly divergent $X$ and $Y$ chromosomes and have become increasingly specialized for male reproduction. Both sex chromosomes have acquired and amplified testis-specific genes, suggestive of roles in spermatogenesis. To understand how the sex chromosome genes participate in the regulation of spermatogenesis, we review genes, including single-copy, multi-copy, and ampliconic genes, whose spermatogenic functions have been demonstrated in mouse genetic studies. Sex chromosomes are subject to chromosome-wide transcriptional silencing in meiotic and postmeiotic stages of spermatogenesis. We also discuss particular sex-linked genes that escape postmeiotic silencing and their evolutionary implications. The unique gene contents and genomic structures of the sex chromosomes reflect their strategies to express genes at various stages of spermatogenesis and reveal the driving forces that shape their evolution.

Free Chinese abstract: A Chinese translation of this abstract is freely available at http://www.reproduction-online.org/content/149/6/ R265/suppl/DC1.
\end{abstract}

Free Japanese abstract: A Japanese translation of this abstract is freely available at http://www.reproduction-online.org/content/149/6/ R265/suppl/DC2.

Reproduction (2015) 149 R265-R277

\section{Introduction}

Mammalian sex chromosomes arose from an ordinary pair of autosomes 200-300 million years ago (Ohno 1967, Lahn \& Page 1999, Bellott et al. 2014). Since then, the X has preserved most of the ancestral autosomal genes, while the $\mathrm{Y}$ has lost most of them and only kept a selective group of critical genes (Skaletsky et al. 2003, Bellott et al. 2010, 2014, Hughes et al. 2010, 2012, Mueller et al. 2013, Soh et al. 2014). Remarkably, both chromosomes have acquired a substantial amount of ampliconic sequences, from which amplified genes are expressed predominantly in the testicular germ cells (Bellott etal. 2010, Mueller et al. 2013, Soh et al. 2014). Several ancestral genes on the human and mouse $\mathrm{Y}$ chromosomes are also found to undergo amplification and change their broad expression pattern to a testis-specific one (Bellott et al. 2014, Soh et al. 2014). These findings suggest an evolutionary trend of increasing specialization for male reproduction for the sex chromosomes.

Male reproduction relies on functional spermatogenesis, which consists of cells of four major differentiation stages: spermatogonia (mitotic), spermatocytes (meiotic), spermatids (postmeiotic; spermiogenic), and spermatozoa (sperm) (Fig. 1). Spermatogenesis genes are abundant in sex chromosomes. Based on the genomic structures, these genes can be divided into two major groups: single-copy genes and ampliconic/multi-copy genes. The majority of single-copy genes involved in spermatogenesis are ancestral genes and they tend to be broadly expressed in the body (examples in Table 1). There are also a small group of single-copy genes that are specifically expressed in the spermatogenic cells, some of which have been shown to exert critical functions in spermatogenesis (Wang et al. 2001, Zheng et al. 2010). In contrast, most of the ampliconic/multi-copy genes were acquired following the divergence of the $X$ and $Y$ chromosomes and are expressed predominantly in the male germline. Interestingly, a few newly acquired genes on the sex chromosomes that have not been amplified, for instance, Prssly and Teyorf1 on the mouse Y chromosome (Soh et al. 2014), also show a germlinespecific expression pattern.

Spermatogenic cells undergo meiosis to generate haploid gametes (Fig. 1). Unlike autosomes that undergo synapsis along their entire lengths during meiosis, large 


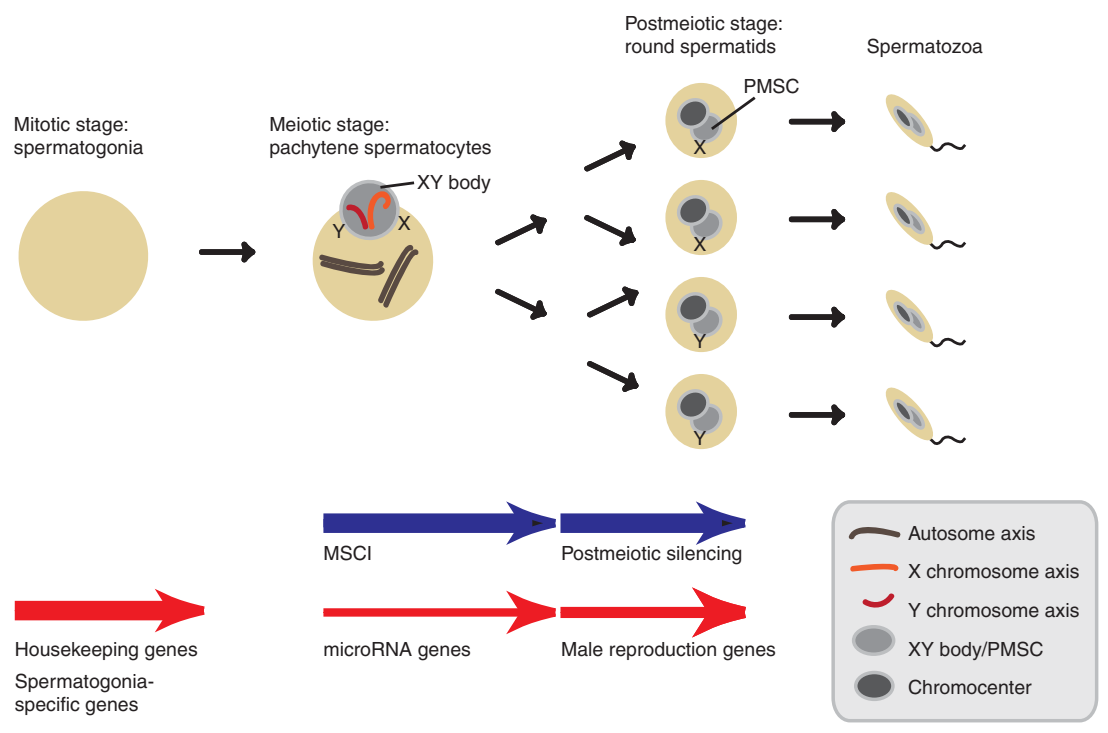

Figure 1 Schematic representation of spermatogenesis and events on the sex chromosomes. Owing to sex chromosome inactivation, sex chromosomes function in two critical phases: before meiosis in mitotically proliferating spermatogonia and after meiosis in haploid spermatids. Blue arrows: two stages of sex chromosome inactivation. Red arrows: groups of genes expressed from the sex chromosomes. regions of the $X$ and $Y$ chromosomes remain unsynapsed and trigger transcriptional silencing, called meiotic sex chromosome inactivation (MSCl: reviewed previously (Turner 2007, van der Heijden et al. 2011, Ichijima et al. 2012)). MSCl is accompanied by the formation of distinct heterochromatin called the XY body (also known as the sex body). This chromosome-wide silencing is maintained into round spermatids by postmeiotic sex chromatin (PMSC; Greaves et al. 2006, Namekawa et al. 2006, Turner et al. 2006). Importantly, there is a group of sex-linked genes that escape postmeiotic silencing and become expressed in postmeiotic spermatids (reviewed previously Sin \& Namekawa (2013)). The regulatory mechanisms by which sex-linked genes are inactivated by $\mathrm{MSCl}$ and activated to escape postmeiotic silencing were identified as DNA damage response pathways adopted from somatic machinery to recognize damaged DNA (Turner et al. 2004, Ichijima et al. 2011, Sin et al. 2012a, Broering et al. 2014). The genes that escape postmeiotic silencing, termed escape genes, include most of the ampliconic/ multi-copy genes, as well as many single-copy genes, on both $X$ and $Y$ chromosomes (Toure et al. 2004a, Cocquet et al. 2009). Therefore, the unique gene contents and genomic structures of the sex chromosomes reflect their strategies to express genes during critical stages of spermatogenesis. In this review article, we summarize the genomic structure of the sex chromosomes and the functions of single-copy and ampliconic/multi-copy genes in the regulation of spermatogenesis, and shed light on the evolution of their unique genomic properties.

\section{Genomic structure of the sex chromosomes}

The differentiation of the sex chromosomes from ancestral autosomes was initiated when one of the autosome pairs acquired a sex-determining gene and underwent chromosomal inversion that prevented recombination in the region (Lahn \& Page 1999, Bellott et al. 2014). Since then, the $X$ and $Y$ chromosomes have evolved in their own way (described below), but share a striking common feature: gaining specialization for male reproduction through acquisition and amplification of testis-specific genes (Skaletsky et al. 2003, Warburton et al. 2004, Ross et al. 2005, Mueller et al. 2008, 2013, Hughes et al. 2010, 2012, Bellott et al. 2014, Soh et al. 2014). The recent improvement in the accuracy of sex chromosome sequence assemblies, by means of the single-haplotype iterative mapping and sequencing (SHIMS) technique, has allowed for detailed annotation of large palindromic and/or ampliconic sequences and for comparisons of sex chromosomes among species (Skaletsky et al. 2003, Bellott et al. 2010, 2014, Hughes et al. 2010, 2012, Mueller et al. 2013, Soh et al. 2014).

\section{$X$ chromosome}

The present-day human $\mathrm{X}$ chromosome has preserved $98 \%$ of genes from the ancestral autosome; however, due to an intergenic expansion of non-coding sequences (particularly long interspersed repeat elements and retroviral sequences) during evolution, the gene density on the $\mathrm{X}$ chromosome is about half of the average of all autosomes (Bailey et al. 2000, Lander et al. 2001, Ross et al. 2005, Bellott et al. 2010). Despite the low gene density, the $X$ chromosome has acquired a substantial number of protein-coding genes, the majority of which are members of multi-copy gene families, including cancer/testis antigen genes, and exhibit testis-predominant expression patterns (Scanlan et al. 2004, Bellott et al. 2010, Mueller et al. 2013). These features are also observed in the sex chromosomes of other mammals, such as chimpanzees, rhesus monkeys, and mice 
(Soh et al. 2014). In the avian ZW system, the $Z$ chromosome that is shared by both sexes (equivalent to the $X$ chromosome in the $X Y$ system, though males are the homogametic sex) also has a lower gene density than the autosomes due to increased intergenic distances, and contains a massive tandem amplification of genes that are expressed in the testis (Bellott et al. 2010). Thus, the convergent acquisition and amplification of testis-expressed genes biases the $X$, as well as Z, chromosomes toward male reproduction functions.

\section{Y chromosome}

The human $\mathrm{Y}$ chromosome retains only $3 \%$ of its ancestral genes, due to a lack of a crossover partner in the malespecific region, leading to genetic decay (Skaletsky et al. 2003, Bellott et al. 2010). Since the start of its differentiation, the human $\mathrm{Y}$ chromosome has undergone evolutionary decay at least four times in a step-wise manner, as evidenced by the presence of the 'evolutionary strata' of the X-Y pairs of ancestral genes (Lahn \& Page 1999). After each event that created a stratum (e.g., chromosomal inversions), genes in the newly nonrecombining region of the $Y$ chromosome decayed rapidly at first, followed by a stable phase, leaving a constant set of surviving genes (Hughes et al. 2012). These surviving ancestral genes were selected during evolution for their critical functions in males: male sex determination, sperm production, and viability (Bellott et al. 2014). In addition to surviving ancestral genes, the $Y$ chromosome acquired and amplified genes that are predominantly expressed in the testis (Skaletsky et al. 2003, Hughes et al. 2010, 2012, Soh et al. 2014). Interestingly, ancestral genes on the human Y chromosome, such as Rbmy, Tspy, and Hsfy, evolved into multi-copy and testis-specific genes, in contrast to other Y-linked ancestral genes, which are broadly expressed (Bellott et al. 2014). Two ancestral genes on the mouse $Y$ chromosome, Rbmy and Zfy, have also undergone amplification and turned into germ cell-specific genes (Mardon et al. 1989, Mahadevaiah et al. 1998, Soh et al. 2014, Vernet et al. 2014).

\section{Lineage-specific acquisition and amplification}

The amplified testis-specific genes on the $X$ and $Y$ chromosomes are rapidly evolving and demonstrate relatively recent and lineage-specific acquisition (Hughes et al. 2010, Mueller et al. 2013, Soh et al. 2014). The recent improvement in the accuracy of the human and mouse sex chromosome sequence assemblies allows for a detailed comparison of the ampliconic regions between the two species (Mueller et al. 2013, Soh et al. 2014). Different from the singlecopy genes that are highly conserved among placental mammals, most of the ampliconic genes are independently acquired and amplified between the human and mouse lineages (Mueller et al. 2013, Soh et al. 2014). Similarly, a comparison of the $Y$ chromosome sequence between human and a closely related species, chimpanzee, also suggests a substantial change in the gene content and genomic structures in the ampliconic regions (Hughes et al. 2010). Therefore, both $X$ and $Y$ chromosomes are subject to selective evolutionary forces that increase specialization for lineage-specific male reproductive functions.

\section{Functions of single-copy genes vs ampliconic/ multi-copy genes during spermatogenesis}

Spermatogenesis is a biological process where self-renewing mitotic spermatogonia give rise to mature spermatozoa through two major differentiation steps: meiosis and spermiogenesis. Spermatogenic cells reside in the testis, which provides a somatic environment to support spermatogenesis. Two major somatic cell types are Sertoli cells (which nourish germ cells through stages of spermatogenesis within the seminiferous tubule) and Leydig cells (which produce and regulate hormones, such as androgens). According to currently available mouse genetic studies, genes on the sex chromosomes regulate spermatogenesis in many different ways (Table 1). Most $X$-linked single-copy genes that exhibit function in spermatogenesis are expressed in multiple tissues and control the process through somatic and/or germ cells, but a small group of spermatogonially expressed, germ cellspecific genes have also been identified (Wang et al. 2001). With the exception of the male sex-determining gene, Sry, surviving ancestral Y-linked single-copy genes are broadly expressed, both in the adult and throughout development (Bellott et al. 2014). In contrast, ampliconic/multi-copy genes on the sex chromosomes tend to be expressed specifically in male germ cells, with potential roles in postmeiotic spermatids (Mueller et al. 2008, 2013, Reynard et al. 2009, Cocquet et al. 2010, Riel et al. 2013, Comptour et al. 2014). In this section, we provide examples of singlecopy and ampliconic/multi-copy genes from mouse genetic studies in the regulation of spermatogenesis.

\section{X-linked spermatogonial genes}

A systematic genomic screen for spermatogonially expressed, germ cell-specific genes in mice has identified 36 genes, 11 of which are on the $X$ chromosome and three of which are on the $Y$ chromosome (Wang et al. 2001). Further genetic studies on four out of the 11 X-linked genes (Tex11, Taf7l, Nxf2, and Tkt/1) in mice have been reported. Tex11 is critical for meiotic prophase by promoting synapsis and crossover formation in spermatocytes. Deletion of Tex11 spanning from exon 3 to exon 29 leads to apoptosis of spermatocytes at the pachytene stage due to meiotic failure (Yang et al. 2008). However, a different Tex11 mutant mouse line, with a 
Table 1 Sex-chromosome genes shown to contribute to male fertility in mouse genetic studies.

\begin{tabular}{|c|c|c|c|c|c|}
\hline $\begin{array}{l}\text { Gene } \\
\text { name }\end{array}$ & $\begin{array}{l}\text { Biological } \\
\text { function }\end{array}$ & Expression & $\begin{array}{l}\text { Human homolog on the } \\
\mathrm{X} \text {; associated diseases }\end{array}$ & $\begin{array}{l}\text { Fertility phenotype of genetically } \\
\text { altered XY mice }\end{array}$ & References \\
\hline \multicolumn{6}{|c|}{ X-linked genes } \\
\hline Abcd1 & $\begin{array}{l}\text { Peroxisomal trans- } \\
\text { porter of very } \\
\text { long-chain fatty } \\
\text { acids }\end{array}$ & Multiple tissues & $\begin{array}{l}\text { Yes; adrenoleukody- } \\
\text { strophy }\end{array}$ & $\begin{array}{l}\text { Reduced fertility; increased number } \\
\text { of interstitial cells with } \\
\text { accumulated lipid inclusions }\end{array}$ & Forss-Petter et al. (1997) \\
\hline Akap4 & $\begin{array}{l}\text { A-kinase anchoring } \\
\text { protein }\end{array}$ & $\begin{array}{l}\text { Spermatids, } \\
\text { spermatozoa }\end{array}$ & Yes & $\begin{array}{l}\text { Infertility; abnormal sperm flagel- } \\
\text { lum morphology and motility }\end{array}$ & Miki et al. (2002) \\
\hline$A r$ & Androgen receptor & Multiple tissues & $\begin{array}{l}\text { Yes; androgen insensi- } \\
\text { tivity syndrome }\end{array}$ & $\begin{array}{l}\text { Infertility; testicular feminization; } \\
\text { impaired spermatogenesis; tissue- } \\
\text { specific KOs indicate that AR } \\
\text { signaling in Sertoli, Leydig, and } \\
\text { peritubular myoid cells is crucial } \\
\text { for spermatogenesis }\end{array}$ & $\begin{array}{l}\text { Lyon \& Hawkes (1970), } \\
\text { Yeh et al. (2002), Chang } \\
\text { et al. (2004), De Gendt } \\
\text { et al. (2004), Holdcraft } 8 \\
\text { Braun (2004), Zhang } \\
\text { et al. (2006) and } \\
\text { Xu et al. (2007) }\end{array}$ \\
\hline $\operatorname{Arx}$ & $\begin{array}{l}\text { Homeodomain } \\
\text { transcription } \\
\text { factor }\end{array}$ & Multiple tissues & $\begin{array}{l}\text { Yes; early-onset epileptic } \\
\text { encephalopathy } 1 \text { and } \\
\text { Partington syndrome }\end{array}$ & $\begin{array}{l}\text { Small testis; fetal Leydig cell } \\
\text { differentiation defect }\end{array}$ & $\begin{array}{l}\text { Kitamura et al. (2002) and } \\
\text { Miyabayashi et al. } \\
\text { (2013) }\end{array}$ \\
\hline Atp $7 a$ & $\begin{array}{l}\text { Copper transpoting } \\
\text { ATPase }\end{array}$ & Multiple tissues & Yes; Menkes disease & $\begin{array}{l}\text { Infertility; spermatogenic cell death; } \\
\text { poor sperm morphology and } \\
\text { motility }\end{array}$ & $\begin{array}{l}\text { Llanos et al. (2006), } \\
\text { Kotula-Balak et al. (2007 } \\
\text { and Kowal et al. (2010) }\end{array}$ \\
\hline$C d k 16$ & $\begin{array}{l}\text { Cyclin-dependent } \\
\text { kinase }\end{array}$ & Multiple tissues & Yes & $\begin{array}{l}\text { Infertility; abnormal sperm } \\
\text { morphology and motility }\end{array}$ & Mikolcevic et al. (2012) \\
\hline Dmd & Dystrophin & Multiple tissues & $\begin{array}{l}\text { Yes; Duchenne and } \\
\text { Becker muscular } \\
\text { dystrophy }\end{array}$ & $\begin{array}{l}\text { Reduced fertility; abnormal } \\
\text { sperm flagellum morphology } \\
\text { and motility }\end{array}$ & $\begin{array}{l}\text { Hernandez-Gonzalez et al } \\
(2005) \text { and Kudoh et al. } \\
\text { (2005) }\end{array}$ \\
\hline Fmr1 & $\begin{array}{l}\text { Fragile } X \text { mental } \\
\text { retardation } \\
\text { protein }\end{array}$ & Multiple tissues & Yes; Fragile $\mathrm{X}$ syndrome & $\begin{array}{l}\text { Macroorchidism-associated } \\
\text { increase in Sertoli cell proli- } \\
\text { feration; defective synapsis } \\
\text { and crossover formation in } \\
\text { spermatocytes }\end{array}$ & $\begin{array}{l}\text { Slegtenhorst-Eegdeman } \\
\text { et al. (1998) and } \\
\text { Alpatov et al. (2014) }\end{array}$ \\
\hline Foxp3 & $\begin{array}{l}\text { Forkhead transcrip- } \\
\text { tion factor }\end{array}$ & Multiple & $\begin{array}{l}\text { Yes; immunodys- } \\
\text { regulation, poly- } \\
\text { endocrinopathy, } \\
\text { enteropathy }\end{array}$ & $\begin{array}{l}\text { Infertility; hypogonadism and } \\
\text { arrested spermatogenesis caused } \\
\text { by insufficient pituitary gonado- } \\
\text { tropins }\end{array}$ & Jasurda et al. (2014) \\
\hline Gpr64 & $\begin{array}{l}\text { G protein-coupled } \\
\text { receptor }\end{array}$ & $\begin{array}{l}\text { Proximal epidi- } \\
\text { dymis, efferent } \\
\text { ductules }\end{array}$ & Yes & $\begin{array}{l}\text { Age-dependent infertility; accumu- } \\
\text { lation of spermatozoa in the } \\
\text { efferent ductules caused by } \\
\text { defective fluid reabsorption }\end{array}$ & Davies et al. (2004) \\
\hline Gria3 & $\begin{array}{l}\text { Ionotropic } \\
\text { glutamate } \\
\text { receptor }\end{array}$ & Multiple tissues & $\begin{array}{l}\text { Yes; mental retardation } \\
\text { X-linked } 94\end{array}$ & $\begin{array}{l}\text { Reduced fertility with unknown } \\
\text { causes }\end{array}$ & Meng et al. (2003) \\
\hline L1cam & $\begin{array}{l}\text { Neural cell } \\
\text { adhesion } \\
\text { molecule }\end{array}$ & Multiple tissues & $\begin{array}{l}\text { Yes; hydrocephalus, } \\
\text { CRASH and MASA } \\
\text { syndromes }\end{array}$ & $\begin{array}{l}\text { Infertility at high frequency with } \\
\text { unknown causes }\end{array}$ & Cohen et al. (1998) \\
\hline Мeсp2 & $\begin{array}{l}\text { Methyl CpG- } \\
\text { binding protein }\end{array}$ & Multiple tissues & Yes; Rett syndrome & Infertility; cryptorchidism & Guy et al. (2001) \\
\hline NrOb1 & Nuclear receptor & Multiple tissues & $\begin{array}{l}\text { Yes; 46XY sex reversal; } \\
\text { adrenal hypoplasia }\end{array}$ & $\begin{array}{l}\text { Infertility; impaired spermato- } \\
\text { genesis; multiple defects in } \\
\text { Sertoli, Leydig, and peritubular } \\
\text { myoid cells }\end{array}$ & $\begin{array}{l}\text { Yu et al. (1998), Jeffs et al. } \\
\text { (2001) and Meeks et al. } \\
\text { (2003) }\end{array}$ \\
\hline$N x f 2$ & $\begin{array}{l}\text { Nuclear RNA export } \\
\text { factor }\end{array}$ & Spermatogonia & Yes & $\begin{array}{l}\text { Reduced fertility; age-dependent } \\
\text { depletion of spermatogonial cells; } \\
\text { meiotic arrest; reduced sperm } \\
\text { count and motility }\end{array}$ & Pan et al. (2009) \\
\hline Pcyt1b & $\begin{array}{l}\text { CTP: phospho- } \\
\text { choline cytidylyl- } \\
\text { transferase }\end{array}$ & Multiple tissues & Yes & $\begin{array}{l}\text { Reduced fertility; age-dependent } \\
\text { depletion of spermatogonial cells }\end{array}$ & Jackowski et al. (2004) \\
\hline Porcn & $\begin{array}{l}\text { Membrane-bound } \\
\text { O-acyl } \\
\text { transferase }\end{array}$ & Multiple tissues & $\begin{array}{l}\text { Yes; focal dermal } \\
\text { hypoplasia }\end{array}$ & $\begin{array}{l}\text { Small testis; abnormal vas deferens } \\
\text { morphology }\end{array}$ & Liu et al. (2012) \\
\hline $\operatorname{Prd} \times 4$ & Peroxiredoxin & Multiple tissues & Yes & $\begin{array}{l}\text { Reduced testis weight; increased } \\
\text { spermatogenic cell death by } \\
\text { oxidative damage; reduced sperm } \\
\text { counts }\end{array}$ & luchi et al. (2009) \\
\hline Rhox5 & $\begin{array}{l}\text { Reproductive } \\
\text { homeodomain } \\
\text { transcription } \\
\text { factor }\end{array}$ & Multiple tissues & $Y_{e s}{ }^{a}$ & $\begin{array}{l}\text { Reduced fertility caused by defective } \\
\text { Sertoli cells; increased spermato- } \\
\text { cyte death; reduced sperm counts } \\
\text { and motility }\end{array}$ & Maclean et al. (2005) \\
\hline
\end{tabular}


Table 1 Continued.

\begin{tabular}{|c|c|c|c|c|c|}
\hline $\begin{array}{l}\text { Gene } \\
\text { name }\end{array}$ & $\begin{array}{l}\text { Biological } \\
\text { function }\end{array}$ & Expression & $\begin{array}{l}\text { Human homolog on the } \\
X ; \text { associated diseases }\end{array}$ & $\begin{array}{l}\text { Fertility phenotype of genetically } \\
\text { altered XY mice }\end{array}$ & References \\
\hline Scm/2 & $\begin{array}{l}\text { Epigenetic } \\
\quad \text { regulator, } \\
\text { Polycomb protein }\end{array}$ & $\begin{array}{l}\text { Spermatogenic } \\
\text { cells }\end{array}$ & Yes; Medulloblastomas & $\begin{array}{l}\text { Infertility; suppression of somatic/ } \\
\text { progenitor genes during } \\
\text { spermatogenesis; suppression of } \\
\text { histone } \mathrm{H} 2 \mathrm{~A} \text { ubiquitination on } \\
\text { the sex chromosomes }\end{array}$ & $\begin{array}{l}\text { Hasegawa et al. (2015) and } \\
\quad \text { Luo et al. (2015) }\end{array}$ \\
\hline$S|x / S| x \mid-1$ & Polycomb protein & $\begin{array}{l}\text { Spermatogenic } \\
\text { cells }\end{array}$ & No & $\begin{array}{l}\text { Reduced fertility in single knock- } \\
\text { downs; infertility in double } \\
\text { knockdowns; impaired } \\
\text { spermiogenesis leading } \\
\text { to cell death; abnormal } \\
\text { sperm morphology; } \\
\text { reduced sperm counts } \\
\text { and motility }\end{array}$ & Cocquet et al. $(2010,2012)$ \\
\hline Sms & Spermine synthase & Multiple tissues & $\begin{array}{l}\text { Yes; Snyder-Robinson } \\
\text { syndrome }\end{array}$ & Infertility with unknown causes & White et al. (2013) \\
\hline Sox3 & $\begin{array}{l}\text { High-mobility } \\
\text { group box trans- } \\
\text { cription factor }\end{array}$ & Multiple tissues & $\begin{array}{l}\text { Yes; mental retardation } \\
\text { and panhypo- } \\
\text { pituitarism }\end{array}$ & $\begin{array}{l}\text { Reduced testis weight; spermato- } \\
\text { gonial differentiation defects; } \\
\text { reduced sperm counts }\end{array}$ & $\begin{array}{l}\text { Weiss et al. (2003), } \\
\text { Rizzoti et al. (2004) and } \\
\text { Laronda \& Jameson } \\
(2011)\end{array}$ \\
\hline Taf7l & $\begin{array}{l}\text { TATA box binding } \\
\text { protein (TBP)- } \\
\text { associated factor }\end{array}$ & $\begin{array}{l}\text { Spermatogenic } \\
\text { cells }\end{array}$ & Yes & $\begin{array}{l}\text { Reduced fertility; reduced sperm } \\
\text { counts; abnormal sperm } \\
\text { morphology and motility }\end{array}$ & Cheng et al. (2007) \\
\hline Tex11 & Meiotic protein & $\begin{array}{l}\text { Spermatogenic } \\
\text { cells }\end{array}$ & Yes & $\begin{array}{l}\text { Depletion of spermatocytes caused } \\
\text { by meiotic defects }\end{array}$ & $\begin{array}{l}\text { Adelman \& Petrini (2008) } \\
\text { and Yang et al. (2008) }\end{array}$ \\
\hline$T s c 22 d 3$ & $\begin{array}{l}\text { Glucocorticoid- } \\
\text { induced leucine } \\
\text { zipper protein }\end{array}$ & $\begin{array}{l}\text { Spermatogenic } \\
\text { cells }\end{array}$ & Yes & $\begin{array}{l}\text { Infertility; defects in proliferation } \\
\text { and differentiation of } \\
\text { undifferentiated spermatogonia; } \\
\text { massive cell death during meiotic } \\
\text { prophase }\end{array}$ & Bruscoli et al. (2012) \\
\hline$T s X$ & Non-coding RNA & Multiple tissues & No & $\begin{array}{l}\text { Grossly undisturbed fertility, albeit } \\
\text { smaller testis and partial germ cell } \\
\text { death during meiotic prophase }\end{array}$ & Anguera et al. (2011) \\
\hline$Z f x$ & Zinc finger protein & Multiple tissues & Yes & $\begin{array}{l}\text { Grossly undisturbed fertility, albeit } \\
\text { smaller testis and reduced sperm } \\
\text { counts }\end{array}$ & Luoh et al. (1997) \\
\hline \multicolumn{6}{|c|}{ 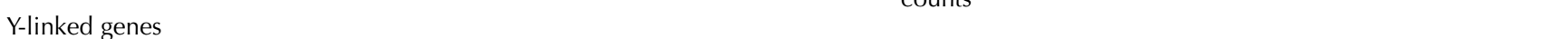 } \\
\hline Sry & $\begin{array}{l}\text { High-mobility } \\
\text { group box tran- } \\
\text { scription factor }\end{array}$ & $\begin{array}{l}\text { Fetal gonad and } \\
\text { brain }\end{array}$ & Yes; 46XY sex reversal & $\begin{array}{l}\text { Infertility; male-to-female } \\
\text { sex reversal }\end{array}$ & $\begin{array}{l}\text { Lovell-Badge \& Robertson } \\
\text { (1990) and Koopman } \\
\text { et al. (1991) }\end{array}$ \\
\hline Eif2s3y & $\begin{array}{l}\text { Translation } \\
\text { initiation factor }\end{array}$ & Multiple tissues & No & $\begin{array}{l}\text { Essential for spermatogonial } \\
\text { proliferation }^{b}\end{array}$ & Mazeyrat et al. (2001) \\
\hline Sly & Sycp3-like Y-linked & $\begin{array}{l}\text { Spermatogenic } \\
\text { cells }\end{array}$ & No & $\begin{array}{l}\text { Reduced fertility; impaired } \\
\text { spermiogenesis; sperm DNA } \\
\text { damage; abnormal sperm } \\
\text { chromatin packaging and } \\
\text { morphology }\end{array}$ & $\begin{array}{l}\text { Cocquet et al. }(2009,2012) \\
\text { and Riel et al. }(2013)\end{array}$ \\
\hline Zfy 1 & $\begin{array}{l}\text { Zinc finger } \\
\text { transcription } \\
\text { factor }\end{array}$ & $\begin{array}{l}\text { Spermatogenic } \\
\text { cells }\end{array}$ & Yes & $\begin{array}{l}\text { Functions in promoting } 2 \text { nd meiotic } \\
\text { divisions in spermatocytes }\end{array}$ & Vernet et al. (2011, 2014) \\
\hline Zfy2 & $\begin{array}{l}\text { Zinc finger } \\
\text { transcription } \\
\text { factor }\end{array}$ & $\begin{array}{l}\text { Spermatogenic } \\
\text { cells }\end{array}$ & Yes & $\begin{array}{l}\text { Functions in meiotic } \\
\text { checkpoints and divisions } \\
\text { in spermatocytes }\end{array}$ & Vernet et al. $(2011,2014)$ \\
\hline
\end{tabular}

${ }^{\mathrm{a}}$ Gene belongs to a Rhox homeobox gene cluster. Owing to a rapid evolution of this gene cluster, a human homolog cannot be precisely defined. ${ }^{\mathrm{b}}$ Genes belong to multi-copy gene families. The phenotypes were demonstrated in male transgenic mice carrying specific siRNA transgenes.

${ }^{\mathrm{C}}$ Gene function was demonstrated by transgene rescue experiments in male mice lacking various portions of the $\mathrm{Y}$ chromosome.

deletion at only exon 3, leads to a premature termination of translation and exhibits milder meiotic defects and normal fertility (Adelman \& Petrini 2008). Taf7l encodes a germ cell-specific subunit of the TFIID complex that is essential for polymerase II-mediated transcription (Pointud et al. 2003, Cheng et al. 2007). Although $\mathrm{Taf} 7 \mathrm{l}$ is expressed in spermatogonia, spermatocytes, and spermatids, its targeted deletion causes a relatively mild phenotype associated with a reduction in sperm counts and sperm motility. The mild phenotype may be due to a functional compensation by its ubiquitously expressed autosomal paralog, Taf7, which was retrotransposed from an mRNA of the Taf7l gene (Pointud et al. 2003, Cheng et al. 2007). Interestingly, Tex11 Taf7l doubleknockout mice show a much more severe meiotic phenotype than either single mutant: an earlier 
spermatocyte death at the zygotene stage, suggesting a synergistic regulation of both genes in meiotic prophase (Zheng et al. 2010). Nxf2, a nuclear mRNA export factor, has implicated its roles in mRNA stability and trafficking (Tretyakova et al. 2005, Lai et al. 2006, Takano et al. 2007). Male mice lacking Nxf2 show reduced fertility, resulting from defects in spermatogonial proliferation and meiotic chromosome segregation (Pan et al. 2009). In contrast to the other three genes, targeted deletion of $T k t / 1$ in mice did not yield any obvious phenotype in reproduction (Bentz et al. 2011).

$S \mathrm{~cm} / 2$, another critical X-linked gene in spermatogenesis, has been recently identified in proteomics screens. SCML2, a germline-specific polycomb protein, was identified as a component of $\gamma \mathrm{H} 2 \mathrm{AX}$ (histone variant $\mathrm{H} 2 \mathrm{AX}$ phosphorylated at serine 139 , an essential histone modification of the $X Y$ body)-containing nucleosomes from testes (Hasegawa et al. 2015). Another proteomics study independently identified SCML2 as a meiosisspecific protein (Luo et al. 2013). Scm/2 is highly transcribed in spermatogonia, but then subject to MSCI in spermatocytes due to its X-linkage (Hasegawa et al. 2015), consistent with a previous report using RNA fluorescence in situ hybridization (FISH) analysis (Mueller et al. 2008). SCML2 protein intensely accumulates in the entire nuclei of undifferentiated spermatogonia but disappears thereafter until the onset of meiosis, where it becomes accumulated on the $X Y$ body despite its transcriptional silencing (Hasegawa et al. 2015, Luo et al. 2015). Scm/2 knockout mice are infertile (Hasegawa et al. 2015), while an independent $S c m / 2$ knockout mouse line with a distinct genetic background exhibits severely compromised fertility (Luo et al. 2015). SCML2 has two distinct functions between autosomes and sex chromosomes in the establishment of the epigenome during spermatogenesis. On autosomes in spermatogonia, SCML2 positively regulates mono-ubiquitinated histone $\mathrm{H} 2 \mathrm{~A}$ at lysine 119 (H2AK119ub) and, during spermatogenic differentiation, suppresses genes commonly expressed among somatic cells as well as spermatogenesis-progenitor genes (Hasegawa et al. 2015). Paradoxically, on sex chromosomes during meiosis, SCML2 also prevents H2AK119ub (Hasegawa et al. 2015, Luo et al. 2015), thereby enabling unique epigenetic programing of sex chromosomes for male reproduction. Therefore, the $\mathrm{X}$ chromosome carries the critical regulator SCML2 for its own gene regulation during spermatogenesis - as is the case for the $\mathrm{X}$-linked Xist non-coding RNA, and the proteins RLIM and ATRX in the regulation of female X chromosome inactivation (Shin et al. 2010, Lee \& Bartolomei 2013, Sarma et al. 2014).

\section{Ancestral single-copy and multi-copy genes}

Male reproduction relies on successful male sex differentiation and development of an individual. Two major genes, Sry and $A r$, which drive male differentiation, are located on the $\mathrm{Y}$ and $\mathrm{X}$ chromosomes respectively (Gubbay et al. 1990, Sinclair et al. 1990, Wang et al. 2009). Sry initiates testis differentiation of the bipotential gonad in mid-gestation (Koopman et al. 1991). The testis then secretes androgens whose functions are mediated through an androgen receptor, encoded from $A r$, to trigger the differentiation of male sex organs (e.g., external genitalia and internal accessory organs) and secondary characteristics (Wang et al. 2009). While androgen receptor signaling in germ cells is not required for spermatogenesis, androgen receptor signaling in the surrounding Sertoli, Leydig, and peritubular myoid cells plays critical roles in the completion of sperm production (Lyon \& Hawkes 1970, Yeh et al. 2002, Chang et al. 2004, De Gendt et al. 2004, Holdcraft \& Braun 2004, Zhang et al. 2006, $\mathrm{Xu}$ et al. 2007). Other X- and Y-linked genes that have been shown to regulate spermatogenesis, based on mouse genetic studies, are listed in Table 1. In particular, targeted deletion of either Sox3 or Tsc22d3 impairs spermatogonial differentiation (Laronda \& Jameson 2011, Bruscoli et al. 2012). Similar to the function of the spermatogonia-specific gene $N x f 2$, disruption of Pcyt $1 b$ causes an age-dependent depletion of spermatogenic cells, indicating a role in the maintenance of spermatogonial stem cells (Jackowski et al. 2004).

The function of Y-linked genes has been mainly studied in mice carrying spontaneous deletions (for review, see Burgoyne (1998)), due to the difficulty of generating targeted mutations on the $\mathrm{Y}$ chromosome using conventional homologous recombination methods in embryonic stem (ES) cells. Nevertheless, these studies have revealed the critical functions of the $Y$ chromosome in spermatogenesis. The $Y$ chromosome is the only chromosome that is acrocentric in the mouse genome, while all others are telocentric (Mouse Genome Sequencing Consortium et al. 2002, Soh et al. 2014). Its long arm contains the highly amplified germ cell-specific gene families Sly, Srsy, and Ssty, all of which were acquired during the evolution of the rodent lineage (Soh et al. 2014). Mice lacking part or all of the long-arm genes show mild-to-severe defects in sperm morphology, fertilization, and fertility (Suh et al. 1989, Burgoyne et al. 1992, Conway et al. 1994, Toure et al. 2004b). On the short arm, Eif2s3y is the sole factor essential for spermatogonial proliferation (Mazeyrat et al. 2001). In mice lacking the entire $\mathrm{Y}$ chromosome $(\mathrm{XO})$, introduction of two transgenes expressing Sry and Eif2s3y is sufficient to initiate testis differentiation and drive spermatogenesis through meiosis up to the round spermatid stage (Yamauchi et al. 2014). Using similar transgene rescue strategies to study ancestral multi-copy genes on the mouse $Y$ chromosome, Zfy2 is found to play an important function in meiotic checkpoints that remove spermatocytes with synaptic errors (Royo et al. 2010). Zfy2, together with Zfy 1 and $Z f x$ (an $X$ homolog), has been discovered to exert a major role in promoting the completion of the 2 nd division of meiosis (Vernet et al. 2011, 2014). 


\section{Acquired ampliconic/multi-copy genes that escape postmeiotic silencing}

During meiosis in spermatocytes, $\mathrm{MSCl}$ results in an almost complete shutdown of sex-linked genes, besides a few exceptions, such as the non-coding RNA TsX (Anguera et al. 2011) and some microRNA genes (Song et al. 2009). On the other hand, many more sex-linked genes escape from postmeiotic silencing in round spermatids. Based on microarray analysis, 13\% of mouse X-linked genes escape postmeiotic silencing, while $87 \%$ remain repressed in round spermatids (Namekawa et al. 2006). Subsequent studies demonstrated that most ampliconic/multi-copy genes on the mouse $\mathrm{X}$ chromosome (33 gene families, representing $\sim 273$ genes in ampliconic regions and non-ampliconic regions) are highly expressed in the round spermatids (Mueller et al. 2008, Sin et al. 2012b). As conventional targeting knockout strategies cannot be applied to multicopy genes, their function has been investigated through the generation of transgenic mice carrying small interfering RNAs. For instance, using shRNAs to knock down Slx ( $\sim 25$ copies), Slxl1 ( $\sim 14$ copies), or both, mice showed impairments in sperm motility and counts (Mueller et al. 2008). While $S / x$ or $S / x / 1$ knockdown mice were subfertile, double $S / x / S / x / 1$ knockdown mice were sterile due to more apparent defects in spermatid elongation and sperm release (Cocquet et al. 2010). These data suggest that X-linked ampliconic/multi-copy genes escape postmeiotic silencing for a functional role in spermiogenesis.

Additionally, Y-linked ampliconic/multi-copy genes are also known to escape postmeiotic silencing (Toure et al. 2005). For instance, Sly (126 copies) is located on the long arm of the $\mathrm{Y}$ chromosome and expressed in postmeiotic spermatids (Ichijima et al. 2011, 2012, Sin et al. 2012a, Sin \& Namekawa 2013). Using an shRNA transgene to knock down Sly, mice exhibited sperm head abnormalities and reduced fertility (Cocquet et al. 2009). In addition, knockdown of Sly also leads to sperm DNA damage and defective chromatin packaging (Riel et al. 2013). Interestingly, SLY protein accumulates on PMSC, and Sly knockdown causes derepression of sex-linked genes in spermatids, suggesting that Sly escapes postmeiotic silencing to regulate PMSC (Cocquet et al. 2009).

\section{Single-copy genes that escape postmeiotic silencing}

In addition to ampliconic/multi-copy genes, there are also many single-copy genes that escape postmeiotic silencing. One example of a single-copy escape gene from mouse genetic studies is Akap4, a gene critical for sperm motility function by encoding a protein anchoring a critical enzyme, cyclic AMP-dependent protein kinase, in the fibrous sheath of the sperm flagellum (Carrera et al. 1994, Miki et al. 2002). Akap4 belongs to a group of genes that commonly escape postmeiotic silencing in both human and mouse, and is also involved in sperm function in humans (Luconi et al. 2011). Expectedly, deletion of Akap4 in male mice leads to infertility due to abnormal sperm morphology and motility (Miki et al. 2002). On the other hand, not all of the escape genes are essential for fertility. Rlim (also known as Rnf12) escapes postmeiotic silencing in mice; however, Rlim is not required for male fertility, although maternal RLIM is a critical regulator of imprinted $\mathrm{X}$ chromosome inactivation in embryos (Cocquet et al. 2012, Good 2012).

\section{Human sex-linked genes that escape postmeiotic silencing}

In humans, although the involvement of the X chromosome in male fertility is a subject of debate (Stouffs et al. 2009, Stouffs \& Lissens 2012), the Y chromosome micro deletions clearly contribute to spermatogenic defects (Krausz et al. 2011). Escape genes in humans have also been implicated in male infertility. In addition to $A K A P 4$, the $X$-linked single-copy escape gene TEX13A may be associated with azoospermia and abnormal sperm maturation (Lee et al. 2003, Hansen et al. 2010). Mutations of other X-linked escape genes, such as $C U L 4 B$ and AFF2, are associated with hypergonadism and developmental delay, suggesting a possible function in male reproduction (Isidor et al. 2010, Sahoo et al. 2011). Further investigation of escape genes is warranted for a better understanding of human male infertility.

\section{Evolutionary implications of genes that escape postmeiotic silencing}

Recent advances in the biology of sex chromosomes, summarized above, enable us to revisit old evolutionary theories of sex chromosomes. In this section, we discuss the driving forces and strategies that have shaped the evolution of the sex chromosomes. $\mathrm{MSCl}$ is common between eutherians and marsupials (Hornecker et al. 2007, Namekawa et al. 2007), and is considered to have evolved with the emergence of the $\mathrm{XY}$ chromosomes in therian ancestors (Potrzebowski et al. 2008). With this history, gene reactivation within the context of sex chromosome inactivation was a necessary step to acquire the spermiogenesis functions of the sex chromosomes.

The mammalian $X$ chromosome is enriched with male reproductive genes (Wang et al. 2001, Zhang et al. 2010, Sin et al. 2012b). It has been shown that these malebiased genes tend to be those which have been recently acquired on the $X$ chromosome and expressed in round spermatids (Zhang et al. 2010). Acquired genes include both single-copy and ampliconic/multi-copy genes. While genes subject to postmeiotic silencing are highly conserved between humans and mice, male reproductive genes that escape postmeiotic silencing are significantly diverged (Sin et al. 2012b). Compared with non-escape 
genes, escape genes exhibit higher rates of amino acid changes calculated by $\mathrm{Ka} / \mathrm{Ks}$ values (Ka/Ks value: the ratio of the number of non-synonymous substitutions per nonsynonymous site $\left(\mathrm{K}_{\mathrm{a}}\right)$ to the number of synonymous substitutions per synonymous site $\left(K_{s}\right)$ ). In addition, although these escape genes are considered important for sperm function, different species tend to have different sets of escape genes (Sin et al. 2012 b). In the study looking at X-linked escape genes, of 54 mouse and 66 human genes, only 12 of them were common between the two species. For example, Rlim escapes postmeiotic silencing in mice but is subject to postmeiotic silencing in humans (Sin et al. 2012b). It remains unknown as to how the expression change in Rlim between mice and humans affects reproductive fitness. Such expression change in the round spermatids was also observed between two closely related mouse species, suggesting that the expression of escape genes could also be an evolutionary constraint, separating the species (Homolka et al. 2011). Furthermore, 25 out of 54 mouse escape genes are rodent specific, and eight out of 66 human escape genes are primate/ape specific. Such specificities suggest that escape genes evolved rapidly in both sequence and expression patterns and are likely to contribute to reproductive isolation between species (Sin et al. 2012b).

\section{Rice's hypothesis}

These findings are in accordance with long-standing evolutionary theories of sex chromosomes. Owing to sexual antagonisms (i.e., conflicting fitness between males and females during sexual reproduction), the sex chromosomes accumulated sexually antagonistic alleles that are favored in one sex but detrimental to the other (Rice 1984). Rice hypothesized that the $X$ chromosome is enriched for genes benefiting males due to the selection of hemizygously expressed favorable effects in males, while their deleterious effects in females would initially be hidden by heterozygosity (Rice 1984). Similarly, any recessive mutation that is advantageous for male fitness can more probably spread on the $X$ chromosome rather than an autosome, where the effects are masked by heterozygosity and likely to be lost. The $\mathrm{Y}$ chromosome is also predicted to be enriched for male-beneficial genes because of the hemizygous expression of Y-linked genes and selection that only occurs in males.

\section{Ohno's law}

A subsequent study compared the sequences of human and mouse $X$ chromosomes and showed that speciesspecific sequences apparently reside in the ampliconic regions, suggesting that these genes are significantly diverged and are, for the most part, independently acquired between these two species (Mueller et al. 2013). This study challenged Ohno's law (Ohno 1967), stating that the gene contents of the $\mathrm{X}$ chromosome are conserved across placental mammals due to the somatic dosage compensation between the $\mathrm{X}$ chromosome and autosomes (i.e., any translocations between the $X$ chromosome and autosomes would disturb the gene dosage). Genes that are expressed before meiosis and subject to postmeiotic silencing are found to be highly conserved (Sin et al. 2012b) and thus follow Ohno's law. However, ampliconic genes that are predominantly expressed in postmeiotic spermatids escape not only postmeiotic silencing, but also Ohno's law. Therefore, Ohno's law pertains mainly to the genes subject to postmeiotic silencing, whereas sexual antagonism underlies escape gene activation in postmeiotic spermatids, consistent with Rice's hypothesis (Fig. 2). These findings suggest that sex chromosomes face at least two antagonistic evolutionary driving forces: i) sex chromosome inactivation, which preserves the gene content (mostly ancestral genes) among species; and ii) sexual antagonism, which facilitates escape gene activation and the acquisition of new genes.

\section{Intragenomic conflict between $X$ and $Y$ chromosomes}

The human and mouse sex chromosomes contain $X-Y$ pairs of ampliconic gene families that were co-acquired and amplified during their evolution (Skaletsky et al. 2003, Soh et al. 2014). Owing to the high divergence in sequence between these pairs of gene families, it has been thought that they may have resulted from intragenomic conflict, which may affect transmission disorders (or segregation distortion) by the action of selfish genetic

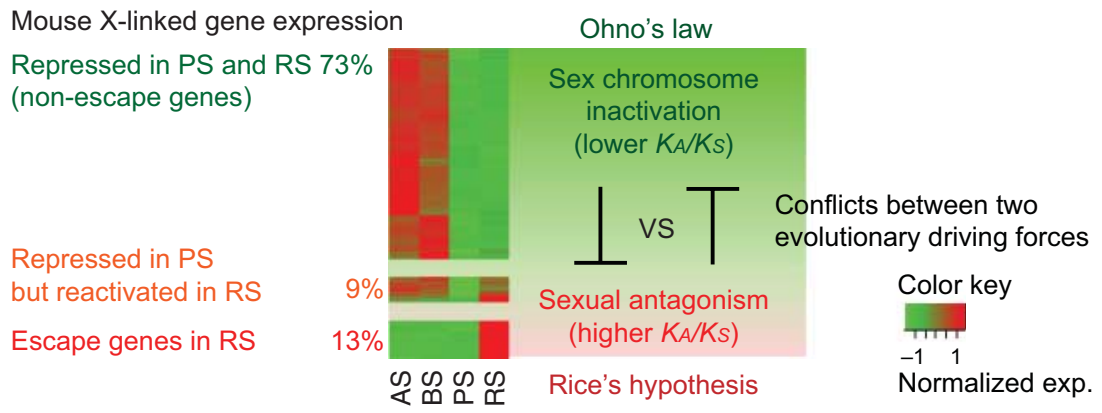

Mouse $\mathrm{X}$-linked gene expression

Repressed in PS and RS 73\%

(non-escape genes)

Reproduction (2015) 149 R265-R277
Figure 2 Model of conflict between two evolutionary driving forces on the $\mathrm{X}$ chromosome. Microarray heatmap adapted from Namekawa et al. (2006). AS, type A spermatogonia; BS, type B spermatogonia; PS, pachytene spermatocytes; RS, round spermatids. 
elements transmitted to the next generation at a frequency higher than the expected Mendelian inheritance ratio. This hypothesis has been tested in mice by knocking down the ampliconic gene family pair: for instance, $S|x|$ SlXI1 on the X chromosome and Sly on the Y chromosome (Cocquet et al. 2012). S/x/SIx/1 deficiency leads to malebiased litters, and Sly deficiency leads to female-biased litters (Cocquet et al. 2009, 2010). However, double knockdown of $S / x / S / x \mid 1$ and $S / y$ rescues the sex ratio distortion phenotype and the fertility problem caused by either knockdown (Cocquet et al. 2012). Based on this result, it was proposed that SLX/SLXL1 and SLY are responsible for intragenomic conflict between $X$ - and Y-bearing sperm by differentially regulating sperm function (Cocquet et al. 2012, Good 2012). Further, Y-linked SSTY also localizes on PMSC, interacts with SLX/ SLX1 and SLY, and is proposed to be involved in the intragenomic conflict (Comptour et al. 2014). Similar to Slx/SIx/1-Sly, other acquired ampliconic gene family pairs on the mouse sex chromosomes, including Sstx-Ssty $1 /$ Ssty 2 and Srsx-Srsy, are rodent specific and show significant divergence in copy number and sequence (Soh et al. 2014). Taken together, the intragenomic conflict has an important impact on the evolution of sex chromosomes by co-acquiring and amplifying genes that escape postmeiotic silencing and regulate spermatid differentiation, which is in line with Rice's hypothesis. Given that these genes are rapidly evolving in a lineage-specific manner, they may also contribute to the speciation process.

\section{Concluding remark}

Mammalian sex chromosomes possess unique genomic features and gene expression that might have conferred an advantage in reproductive fitness of the species. Sequence analysis has revealed that both the $X$ and $Y$ chromosomes contain testis-specific ampliconic/ multi-copy gene families, most of which were acquired during recent evolution, and some of which were derived from ancestral single-copy genes. Many of these genes escape postmeiotic silencing, suggesting that they exert important functions in spermatid differentiation and maturation. As they are rapidly evolving and are highly divergent in gene content among species, it is thought that they contribute to the speciation process. Similar to ampliconic/multi-copy genes, single-copy escape genes are found to evolve rapidly in sequence and vary markedly between human and mouse (Sin et al. 2012b). Therefore, the accumulation of ampliconic/multi-copy genes and genes escaping postmeiotic silencing on the sex chromosomes is likely to benefit male reproduction in a lineage-specific manner, thus supporting Rice's hypothesis (Fig. 2). In contrast, genes that are subject to postmeiotic silencing tend to be more conserved and thus follow Ohno's law (Fig. 2). Therefore, these antagonistic driving forces and strategies have shaped the evolution of the sex chromosomes.

\section{Looking forward}

In spite of accumulating evidence, the mechanisms that drive unique genomic arrangements and expression, such as amplification of genomic elements and escape from postmeiotic silencing, remain unknown. A promising path for future investigation is to identify the potential mechanisms that induce gene amplification and regulate gene expression during the postmeiotic period of spermatogenesis. Curiously, ampliconic DNA regions exhibit unique epigenetic signatures, such as DNA hypomethylation, throughout the germline before gene activation (Ikeda et al. 2013). It suggests that the uniquely evolved ampliconic sequences are distinctly regulated during spermatogenesis.

Furthermore, in humans, sex chromosome abnormalities such as Klinefelter (XXY) and Turner (XO) syndromes are associated with infertility, suggesting that the gene dosage of the sex chromosomes is also critical for fertility both in males and females (Heard \& Turner 2011). Thus, in addition to the function of individual genes, the chromosome-wide regulation of gene dosage of the sex chromosomes may be warranted for further investigation.

Another interesting direction for future investigation is the relationship between the function of sex-chromosome genes and some types of cancer. Large palindromic and/or repetitive sequences of the sex chromosomes are enriched with cancer/testis (CT) antigens that are commonly expressed in testes and cancer (Simpson et al. 2005). Unique genomic and epigenomic features likely underlie germline-specific gene activation on the sex chromosomes, as well as ectopic expression in some types of cancers. It would be intriguing to investigate how the germline program recapitulates in the case of abnormal somatic cells such as cancer cells, and how to safeguard and maintain our genome through the germline. The extraordinary genomic structure and genetic complement of sex chromosomes are likely to be key players in such processes.

\section{Declaration of interest}

The authors declare that there is no conflict of interest that could be perceived as prejudicing the impartiality of the review.

\section{Funding}

This work was supported by the endowment from the Perinatal Institute and Cincinnati Children's Hospital Medical Center to $\mathrm{Y}-\mathrm{C} \mathrm{Hu}$, the Developmental Fund at Cincinnati Children's Hospital Medical Center to S H Namekawa, the Research Grant from the March of Dimes Foundation to S H Namekawa, and NIH Grant GM098605 to S H Namekawa. 


\section{Acknowledgements}

The authors thank Tyler J Broering and Kris G Alavattam for editing, and Daniel W Bellott for critical comments on the manuscript.

\section{References}

Adelman CA \& Petrini JH 2008 ZIP4H (TEX11) deficiency in the mouse impairs meiotic double strand break repair and the regulation of crossing over. PLoS Genetics 4 e1000042. (doi:10.1371/journal.pgen.1000042)

Alpatov R, Lesch BJ, Nakamoto-Kinoshita M, Blanco A, Chen S, Stutzer A, Armache KJ, Simon MD, Xu C, Ali M et al. 2014 A chromatin-dependent role of the fragile $X$ mental retardation protein FMRP in the DNA damage response. Cell 157 869-881. (doi:10.1016/j.cell.2014.03.040)

Anguera MC, Ma W, Clift D, Namekawa S, Kelleher RJ III \& Lee JT 2011 Tsx produces a long noncoding RNA and has general functions in the germline, stem cells, and brain. PLoS Genetics 7 e1002248. (doi:10. 1371/journal.pgen.1002248)

Bailey JA, Carrel L, Chakravarti A \& Eichler EE 2000 Molecular evidence for a relationship between LINE-1 elements and X chromosome inactivation: the Lyon repeat hypothesis. PNAS 97 6634-6639. (doi:10.1073/pnas.97. 12.6634)

Bellott DW, Skaletsky H, Pyntikova T, Mardis ER, Graves T, Kremitzki C, Brown LG, Rozen S, Warren WC, Wilson RK et al. 2010 Convergent evolution of chicken $Z$ and human $X$ chromosomes by expansion and gene acquisition. Nature 466 612-616. (doi:10.1038/nature09172)

Bellott DW, Hughes JF, Skaletsky H, Brown LG, Pyntikova T, Cho TJ, Koutseva N, Zaghlul S, Graves T, Rock S et al. 2014 Mammalian Y chromosomes retain widely expressed dosage-sensitive regulators. Nature 508 494-499. (doi:10.1038/nature13206)

Bentz S, Pesch T, Wolfram L, de Valliere C, Leucht K, Fried M, Coy JF, Hausmann M \& Rogler G 2011 Lack of transketolase-like (TKTL) 1 aggravates murine experimental colitis. American Journal of Physiology. Gastrointestinal and Liver Physiology 300 G598-G607. (doi:10.1152/ ajpgi.00323.2010)

Broering TJ, Alavattam KG, Sadreyev RI, Ichijima Y, Kato Y, Hasegawa K, Camerini-Otero RD, Lee JT, Andreassen PR \& Namekawa SH 2014 BRCA1 establishes DNA damage signaling and pericentric heterochromatin of the $X$ chromosome in male meiosis. Journal of Cell Biology 205 663-675. (doi:10.1083/jcb.201311050)

Bruscoli S, Velardi E, Di Sante M, Bereshchenko O, Venanzi A, Coppo M, Berno V, Mameli MG, Colella R, Cavaliere A et al. 2012 Long glucocorticoid-induced leucine zipper (L-GILZ) protein interacts with ras protein pathway and contributes to spermatogenesis control. Journal of Biological Chemistry 287 1242-1251. (doi:10.1074/jbc. M111.316372)

Burgoyne PS 1998 The role of Y-encoded genes in mammalian spermatogenesis. Seminars in Cell \& Developmental Biology 9 423-432. (doi:10.1006/scdb.1998.0228)

Burgoyne PS, Mahadevaiah SK, Sutcliffe MJ \& Palmer SJ 1992 Fertility in mice requires $\mathrm{X}-\mathrm{Y}$ pairing and a Y-chromosomal "spermiogenesis" gene mapping to the long arm. Cell 71 391-398. (doi:10.1016/00928674(92)90509-B)

Carrera A, Gerton GL \& Moss SB 1994 The major fibrous sheath polypeptide of mouse sperm: structural and functional similarities to the A-kinase anchoring proteins. Developmental Biology 165 272-284. (doi:10.1006/dbio.1994.1252)

Chang C, Chen YT, Yeh SD, Xu Q, Wang RS, Guillou F, Lardy H \& Yeh S 2004 Infertility with defective spermatogenesis and hypotestosteronemia in male mice lacking the androgen receptor in Sertoli cells. PNAS 101 6876-6881. (doi:10.1073/pnas.0307306101)

Cheng Y, Buffone MG, Kouadio M, Goodheart M, Page DC, Gerton GL, Davidson I \& Wang PJ 2007 Abnormal sperm in mice lacking the Taf7l gene. Molecular and Cellular Biology 27 2582-2589. (doi:10.1128/ MCB.01722-06)

Cocquet J, Ellis PJ, Yamauchi Y, Mahadevaiah SK, Affara NA, Ward MA \& Burgoyne PS 2009 The multicopy gene Sly represses the sex chromosomes in the male mouse germline after meiosis. PLoS Biology 7 e1000244. (doi:10.1371/journal.pbio.1000244)
Cocquet J, Ellis PJ, Yamauchi Y, Riel JM, Karacs TP, Rattigan A, Ojarikre OA, Affara NA, Ward MA \& Burgoyne PS 2010 Deficiency in the multicopy Sycp3-like X-linked genes SIx and SIxl1 causes major defects in spermatid differentiation. Molecular Biology of the Cell 21 3497-3505. (doi:10.1091/mbc.E10-07-0601)

Cocquet J, Ellis PJ, Mahadevaiah SK, Affara NA, Vaiman D \& Burgoyne PS 2012 A genetic basis for a postmeiotic $X$ versus $Y$ chromosome intragenomic conflict in the mouse. PLoS Genetics 8 e1002900. (doi:10.1371/journal.pgen.1002900)

Cohen NR, Taylor JS, Scott LB, Guillery RW, Soriano P \& Furley AJ 1998 Errors in corticospinal axon guidance in mice lacking the neural cell adhesion molecule L1. Current Biology 8 26-33. (doi:10.1016/S09609822(98)70017-X)

Comptour A, Moretti C, Serrentino ME, Auer J, laly-Radio C, Ward MA, Toure A, Vaiman D \& Cocquet J 2014 SSTY proteins co-localize with the post-meiotic sex chromatin and interact with regulators of its expression. FEBS Journal 281 1571-1584. (doi:10.1111/febs.12724)

Conway SJ, Mahadevaiah SK, Darling SM, Capel B, Rattigan AM \& Burgoyne PS 1994 Y353/B: a candidate multiple-copy spermiogenesis gene on the mouse Y chromosome. Mammalian Genome 5 203-210. (doi:10.1007/BF00360546)

Davies B, Baumann C, Kirchhoff C, Ivell R, Nubbemeyer R, Habenicht UF, Theuring F \& Gottwald U 2004 Targeted deletion of the epididymal receptor HE6 results in fluid dysregulation and male infertility. Molecular and Cellular Biology 24 8642-8648. (doi:10.1128/MCB.24.19.8642-8648.2004)

De Gendt K, Swinnen JV, Saunders PT, Schoonjans L, Dewerchin M, Devos A, Tan K, Atanassova N, Claessens F, Lecureuil C et al. 2004 A Sertoli cell-selective knockout of the androgen receptor causes spermatogenic arrest in meiosis. PNAS 101 1327-1332. (doi:10.1073/ pnas.0308114100)

Forss-Petter S, Werner H, Berger J, Lassmann H, Molzer B, Schwab MH, Bernheimer H, Zimmermann F \& Nave KA 1997 Targeted inactivation of the X-linked adrenoleukodystrophy gene in mice. Journal of Neuroscience Research $50 \quad 829-843 . \quad$ (doi:10.1002/(SICI)10974547(19971201)50:5 < 829::AID-JNR19>3.0.CO;2-W)

Good JM 2012 The conflict within and the escalating war between the sex chromosomes. PLoS Genetics 8 e1002955. (doi:10.1371/journal.pgen. 1002955)

Greaves IK, Rangasamy D, Devoy M, Marshall Graves JA \& Tremethick DJ 2006 The $\mathrm{X}$ and $\mathrm{Y}$ chromosomes assemble into H2A.Z-containing [corrected] facultative heterochromatin [corrected] following meiosis. Molecular and Cellular Biology 26 5394-5405. (doi:10.1128/MCB.00519-06)

Gubbay J, Collignon J, Koopman P, Capel B, Economou A, Munsterberg A, Vivian N, Goodfellow P \& Lovell-Badge R 1990 A gene mapping to the sex-determining region of the mouse $Y$ chromosome is a member of a novel family of embryonically expressed genes. Nature 346 245-250. (doi:10.1038/346245a0)

Guy J, Hendrich B, Holmes M, Martin JE \& Bird A 2001 A mouse Mecp2null mutation causes neurological symptoms that mimic Rett syndrome. Nature Genetics 27 322-326. (doi:10.1038/85899)

Hansen S, Eichler EE, Fullerton SM \& Carrell D 2010 SPANX gene variation in fertile and infertile males. Systems Biology in Reproductive Medicine 55 18-26. (doi:10.3109/19396360903312015)

Hasegawa K, Sin HS, Maezawa S, Broering TJ, Kartashov AV, Alavattam KG, Ichijima Y, Zhang F, Bacon WC, Greis KD et al. 2015 SCML2 establishes the male germline epigenome through regulation of histone H2A ubiquitination. Developmental Cell 32 547-548. (doi:10.1016/j.devcel.2015.01.014)

Heard E \& Turner J 2011 Function of the sex chromosomes in mammalian fertility. Cold Spring Harbor Perspectives in Biology 3 a002675. (doi:10.1101/cshperspect.a002675)

van der Heijden GW, Eijpe M \& Baarends WM 2011 The $X$ and Y chromosome in meiosis: how and why they keep silent. Asian Journal of Andrology 13 779-780. (doi:10.1038/aja.2011.93)

Hernandez-Gonzalez EO, Mornet D, Rendon A \& Martinez-Rojas D 2005 Absence of Dp71 in $\mathrm{mdx} 3 \mathrm{cv}$ mouse spermatozoa alters flagellar morphology and the distribution of ion channels and nNOS. Journal of Cell Science 118 137-145. (doi:10.1242/jcs.01584)

Holdcraft RW \& Braun RE 2004 Androgen receptor function is required in Sertoli cells for the terminal differentiation of haploid spermatids. Development 131 459-467. (doi:10.1242/dev.00957) 
Homolka D, Ivanek R, Forejt J \& Jansa P 2011 Differential expression of non-coding RNAs and continuous evolution of the $X$ chromosome in testicular transcriptome of two mouse species. PLOS ONE 6 e17198. (doi:10.1371/journal.pone.0017198)

Hornecker JL, Samollow PB, Robinson ES, Vandeberg JL \& McCarrey JR 2007 Meiotic sex chromosome inactivation in the marsupial Monodelphis domestica. Genesis 45 696-708. (doi:10.1002/dvg.20345)

Hughes JF, Skaletsky H, Pyntikova T, Graves TA, van Daalen SK, Minx PJ, Fulton RS, McGrath SD, Locke DP, Friedman C et al. 2010 Chimpanzee and human $\mathrm{Y}$ chromosomes are remarkably divergent in structure and gene content. Nature 463 536-539. (doi:10.1038/nature08700)

Hughes JF, Skaletsky H, Brown LG, Pyntikova T, Graves T, Fulton RS, Dugan S, Ding Y, Buhay CJ, Kremitzki C et al. 2012 Strict evolutionary conservation followed rapid gene loss on human and rhesus Y chromosomes. Nature 483 82-86. (doi:10.1038/nature10843)

Ichijima Y, Ichijima M, Lou Z, Nussenzweig A, Camerini-Otero RD, Chen J, Andreassen PR \& Namekawa SH 2011 MDC1 directs chromosome-wide silencing of the sex chromosomes in male germ cells. Genes and Development 25 959-971. (doi:10.1101/gad.2030811)

Ichijima Y, Sin HS \& Namekawa SH 2012 Sex chromosome inactivation in germ cells: emerging roles of DNA damage response pathways. Cellular and Molecular Life Sciences 69 2559-2572. (doi:10.1007/s00018-012-0941-5)

Ikeda R, Shiura H, Numata K, Sugimoto M, Kondo M, Mise N, Suzuki M, Greally JM \& Abe K 2013 Large, male germ cell-specific hypomethylated DNA domains with unique genomic and epigenomic features on the mouse X chromosome. DNA Research 20 549-565. (doi:10.1093/ dnares/dst030)

Isidor B, Pichon O, Baron S, David A \& Le Caignec C 2010 Deletion of the CUL4B gene in a boy with mental retardation, minor facial anomalies, short stature, hypogonadism, and ataxia. American Journal of Medical Genetics. Part A 152A 175-180. (doi:10.1002/ajmg.a.33152)

Iuchi Y, Okada F, Tsunoda S, Kibe N, Shirasawa N, Ikawa M, Okabe M, Ikeda Y \& Fujii J 2009 Peroxiredoxin 4 knockout results in elevated spermatogenic cell death via oxidative stress. Biochemical Journal 419 149-158. (doi:10.1042/BJ20081526)

Jackowski S, Rehg JE, Zhang YM, Wang J, Miller K, Jackson P \& Karim MA 2004 Disruption of CCT $\beta 2$ expression leads to gonadal dysfunction. Molecular and Cellular Biology 24 4720-4733. (doi:10.1128/MCB.24. 11.4720-4733.2004)

Jasurda JS, Jung DO, Froeter ED, Schwartz DB, Hopkins TD, Farris CL, McGee S, Narayan P \& Ellsworth BS 2014 The forkhead transcription factor, FOXP3: a critical role in male fertility in mice. Biology of Reproduction 90 4. (doi:10.1095/biolreprod.113.112375)

Jeffs B, Meeks J, Ito M, Martinson FA, Matzuk MM, Jameson JL \& Russell LD 2001 Blockage of the rete testis and efferent ductules by ectopic Sertoli and Leydig cells causes infertility in Dax1-deficient male mice. Endocrinology 142 4486-4495. (doi:10.1210/endo.142.10.8447)

Kitamura K, Yanazawa M, Sugiyama N, Miura H, lizuka-Kogo A, Kusaka M, Omichi K, Suzuki R, Kato-Fukui Y, Kamiirisa K et al. 2002 Mutation of ARX causes abnormal development of forebrain and testes in mice and $X$-linked lissencephaly with abnormal genitalia in humans. Nature Genetics 32 359-369. (doi:10.1038/ng1009)

Koopman P, Gubbay J, Vivian N, Goodfellow P \& Lovell-Badge R 1991 Male development of chromosomally female mice transgenic for Sry. Nature 351 117-121. (doi:10.1038/351117a0)

Kotula-Balak M, Lenartowicz M, Kowal M, Styrna J \& Bilinska B 2007 Testicular morphology and expression of aromatase in testes of mice with the mosaic mutation (Atp7a mo-ms). Theriogenology 67 423-434. (doi:10.1016/j.theriogenology.2006.08.016)

Kowal M, Lenartowicz M, Pecio A, Golas A, Blaszkiewicz T \& Styrna J 2010 Copper metabolism disorders affect testes structure and gamete quality in male mice. Systems Biology in Reproductive Medicine 56 431-444. (doi:10.3109/19396361003734624)

Krausz C, Chianese C, Giachini C, Guarducci E, Laface I \& Forti G 2011 The $\mathrm{Y}$ chromosome-linked copy number variations and male fertility. Journal of Endocrinological Investigations 34 376-382. (doi:10.3275/ 7612)

Kudoh H, Ikeda H, Kakitani M, Ueda A, Hayasaka M, Tomizuka K \& Hanaoka K 2005 A new model mouse for Duchenne muscular dystrophy produced by $2.4 \mathrm{Mb}$ deletion of dystrophin gene using Cre-loxP recombination system. Biochemical and Biophysical Research Communications 328 507-516. (doi:10.1016/j.bbrc.2004.12.191)
Lahn BT \& Page DC 1999 Four evolutionary strata on the human X chromosome. Science 286 964-967. (doi:10.1126/science.286. 5441.964)

Lai D, Sakkas D \& Huang Y 2006 The fragile X mental retardation protein interacts with a distinct mRNA nuclear export factor NXF2. RNA 12 1446-1449. (doi:10.1261/rna.94306)

Lander ES, Linton LM, Birren B, Nusbaum C, Zody MC, Baldwin J, Devon K, Dewar K, Doyle M, FitzHugh W et al. 2001 Initial sequencing and analysis of the human genome. Nature 409 860-921. (doi:10.1038/ 35057062)

Laronda MM \& Jameson JL 2011 Sox3 functions in a cell-autonomous manner to regulate spermatogonial differentiation in mice. Endocrinology 152 1606-1615. (doi:10.1210/en.2010-1249)

Lee JT \& Bartolomei MS 2013 X-inactivation, imprinting, and long noncoding RNAs in health and disease. Cell 152 1308-1323. (doi:10.1016/j.cell.2013.02.016)

Lee S, Lee SH, Chung TG, Kim HJ, Yoon TK, Kwak IP, Park SH, Cha WT, Cho SW \& Cha KY 2003 Molecular and cytogenetic characterization of two azoospermic patients with X-autosome translocation. Journal of Assisted Reproduction and Genetics 20 385-389. (doi:10.1023/ A:1025437329427)

Liu W, Shaver TM, Balasa A, Ljungberg MC, Wang X, Wen S, Nguyen H \& Van den Veyver IB 2012 Deletion of Porcn in mice leads to multiple developmental defects and models human focal dermal hypoplasia (Goltz syndrome). PLOS ONE 7 e32331. (doi:10.1371/journal.pone. 0032331)

Llanos RM, Ke BX, Wright M, Deal Y, Monty F, Kramer DR \& Mercer JF 2006 Correction of a mouse model of Menkes disease by the human Menkes gene. Biochimica et Biophysica Acta 1762 485-493. (doi:10.1016/j.bbadis.2005.12.011)

Lovell-Badge R \& Robertson E 1990 XY female mice resulting from a heritable mutation in the primary testis-determining gene, Tdy. Development 109 635-646.

Luconi M, Cantini G, Baldi E \& Forti G 2011 Role of a-kinase anchoring proteins (AKAPs) in reproduction. Frontiers in Bioscience 16 1315-1330. (doi:10.2741/3791)

Luo M, Yang F, Leu NA, Landaiche J, Handel MA, Benavente R, La Salle S \& Wang PJ 2013 MEIOB exhibits single-stranded DNA-binding and exonuclease activities and is essential for meiotic recombination. Nature Communications 4 2788. (doi:10.1038/ncomms3788)

Luo M, Zhou J, Leu NA, Abreu CM, Wang J, Anguera MC, de Rooij DG, Jasin M \& Wang PJ 2015 Polycomb protein SCML2 associates with USP7 and counteracts histone $\mathrm{H} 2 \mathrm{~A}$ ubiquitination in the $\mathrm{XY}$ chromatin during male meiosis. PLoS Genetics 11 e1004954. (doi:10.1371/journal.pgen. 1004954)

Luoh SW, Bain PA, Polakiewicz RD, Goodheart ML, Gardner H, Jaenisch R \& Page DC 1997 Zfx mutation results in small animal size and reduced germ cell number in male and female mice. Development 124 2275-2284.

Lyon MF \& Hawkes SG 1970 X-linked gene for testicular feminization in the mouse. Nature 227 1217-1219. (doi:10.1038/2271217a0)

Maclean JA II, Chen MA, Wayne CM, Bruce SR, Rao M, Meistrich ML, Macleod C \& Wilkinson MF 2005 Rhox: a new homeobox gene cluster. Cell 120 369-382. (doi:10.1016/j.cell.2004.12.022)

Mahadevaiah SK, Odorisio T, Elliott DJ, Rattigan A, Szot M, Laval SH, Washburn LL, McCarrey JR, Cattanach BM, Lovell-Badge R et al. 1998 Mouse homologues of the human AZF candidate gene RBM are expressed in spermatogonia and spermatids, and map to a $Y$ chromosome deletion interval associated with a high incidence of sperm abnormalities. Human Molecular Genetics 7 715-727. (doi:10.1093/hmg/7.4.715)

Mardon G, Mosher R, Disteche CM, Nishioka Y, McLaren A \& Page DC 1989 Duplication, deletion, and polymorphism in the sex-determining region of the mouse Y chromosome. Science 243 78-80. (doi:10.1126/ science.2563173)

Mazeyrat S, Saut N, Grigoriev V, Mahadevaiah SK, Ojarikre OA, Rattigan A, Bishop C, Eicher EM, Mitchell MJ \& Burgoyne PS 2001 A Y-encoded subunit of the translation initiation factor Eif2 is essential for mouse spermatogenesis. Nature Genetics 29 49-53. (doi:10.1038/ng717)

Meeks JJ, Crawford SE, Russell TA, Morohashi K, Weiss J \& Jameson JL 2003 Dax1 regulates testis cord organization during gonadal differentiation. Development 130 1029-1036. (doi:10.1242/dev.00316) 
Meng Y, Zhang Y \& Jia Z 2003 Synaptic transmission and plasticity in the absence of AMPA glutamate receptor GluR2 and GluR3. Neuron 39 163-176. (doi:10.1016/S0896-6273(03)00368-4)

Miki K, Willis WD, Brown PR, Goulding EH, Fulcher KD \& Eddy EM 2002 Targeted disruption of the Akap4 gene causes defects in sperm flagellum and motility. Developmental Biology 248 331-342. (doi:10.1006/dbio. 2002.0728)

Mikolcevic P, Sigl R, Rauch V, Hess MW, Pfaller K, Barisic M, Pelliniemi LJ, Boesl M \& Geley S 2012 Cyclin-dependent kinase 16/PCTAIRE kinase 1 is activated by cyclin $\mathrm{Y}$ and is essential for spermatogenesis. Molecular and Cellular Biology 32 868-879. (doi:10.1128/MCB.06261-11)

Miyabayashi K, Katoh-Fukui Y, Ogawa H, Baba T, Shima Y, Sugiyama N, Kitamura K \& Morohashi K 2013 Aristaless related homeobox gene, Arx, is implicated in mouse fetal Leydig cell differentiation possibly through expressing in the progenitor cells. PLOS ONE 8 e68050. (doi:10.1371/ journal.pone.0068050)

Mouse Genome Sequencing Consortium , Waterston RH, Lindblad-Toh K, Birney E, Rogers J, Abril JF, Agarwal P, Agarwala R, Ainscough R, Alexandersson $\mathbf{M}$ et al. 2002 Initial sequencing and comparative analysis of the mouse genome. Nature 420 520-562. (doi:10.1038/ nature01262)

Mueller JL, Mahadevaiah SK, Park PJ, Warburton PE, Page DC \& Turner JM 2008 The mouse $X$ chromosome is enriched for multicopy testis genes showing postmeiotic expression. Nature Genetics 40 794-799. (doi:10.1038/ng.126)

Mueller JL, Skaletsky H, Brown LG, Zaghlul S, Rock S, Graves T, Auger K, Warren WC, Wilson RK \& Page DC 2013 Independent specialization of the human and mouse $X$ chromosomes for the male germ line. Nature Genetics 45 1083-1087. (doi:10.1038/ng.2705)

Namekawa SH, Park PJ, Zhang LF, Shima JE, McCarrey JR, Griswold MD \& Lee JT 2006 Postmeiotic sex chromatin in the male germline of mice. Current Biology 16 660-667. (doi:10.1016/j.cub.2006.01.066)

Namekawa SH, VandeBerg JL, McCarrey JR \& Lee JT 2007 Sex chromosome silencing in the marsupial male germ line. PNAS $\mathbf{1 0 4}$ 9730-9735. (doi:10.1073/pnas.0700323104)

Ohno S 1967 Sex Chromosomes and Sex-linked Genes. Berlin, New York: Springer-Verlag.

Pan J, Eckardt S, Leu NA, Buffone MG, Zhou J, Gerton GL, McLaughlin KJ \& Wang PJ 2009 Inactivation of Nxf2 causes defects in male meiosis and age-dependent depletion of spermatogonia. Developmental Biology 330 167-174. (doi:10.1016/j.ydbio.2009.03.022)

Pointud JC, Mengus G, Brancorsini S, Monaco L, Parvinen M, SassoneCorsi P \& Davidson I 2003 The intracellular localisation of TAF7L, a paralogue of transcription factor TFIID subunit TAF7, is developmentally regulated during male germ-cell differentiation. Journal of Cell Science 116 1847-1858. (doi:10.1242/jcs.00391)

Potrzebowski L, Vinckenbosch N, Marques AC, Chalmel F, Jégou B \& Kaessmann H 2008 Chromosomal gene movements reflect the recent origin and biology of therian sex chromosomes. PLoS Biology 6 e80. (doi:10.1371/journal.pbio.0060080)

Reynard LN, Cocquet J \& Burgoyne PS 2009 The multi-copy mouse gene Sycp3-like Y-linked (Sly) encodes an abundant spermatid protein that interacts with a histone acetyltransferase and an acrosomal protein. Biology of Reproduction 81 250-257. (doi:10.1095/biolreprod.108.075382)

Rice WR 1984 Sex chromosomes and the evolution of sexual dimorphism. Evolution 38 735-742. (doi:10.2307/2408385)

Riel JM, Yamauchi Y, Sugawara A, Li HY, Ruthig V, Stoytcheva Z, Ellis PJ, Cocquet J \& Ward MA 2013 Deficiency of the multi-copy mouse Y gene Sly causes sperm DNA damage and abnormal chromatin packaging. Journal of Cell Science 126 803-813. (doi:10.1242/jcs.114488)

Rizzoti K, Brunelli S, Carmignac D, Thomas PQ, Robinson IC \& Lovell-Badge R 2004 SOX3 is required during the formation of the hypothalamo-pituitary axis. Nature Genetics 36 247-255. (doi:10.1038/ng1309)

Ross MT, Grafham DV, Coffey AJ, Scherer S, McLay K, Muzny D, Platzer M, Howell GR, Burrows C, Bird CP et al. 2005 The DNA sequence of the human X chromosome. Nature 434 325-337. (doi:10.1038/ nature03440)

Royo H, Polikiewicz G, Mahadevaiah SK, Prosser H, Mitchell M, Bradley A, de Rooij DG, Burgoyne PS \& Turner JM 2010 Evidence that meiotic sex chromosome inactivation is essential for male fertility. Current Biology 20 2117-2123. (doi:10.1016/j.cub.2010.11.010)
Sahoo T, Theisen A, Marble M, Tervo R, Rosenfeld JA, Torchia BS \& Shaffer LG 2011 Microdeletion of Xq28 involving the AFF2 (FMR2) gene in two unrelated males with developmental delay. American Journal of Medical Genetics. Part A 155A 3110-3115. (doi:10.1002/ajmg.a.34345) Sarma K, Cifuentes-Rojas C, Ergun A, Del Rosario A, Jeon Y, White F, Sadreyev R \& Lee JT 2014 ATRX directs binding of PRC2 to Xist RNA and polycomb targets. Cell 159 869-883. (doi:10.1016/j.cell.2014.10.019)

Scanlan MJ, Simpson AJ \& Old LJ 2004 The cancer/testis genes: review, standardization, and commentary. Cancer Immunity 41.

Shin J, Bossenz M, Chung Y, Ma H, Byron M, Taniguchi-Ishigaki N, Zhu X, Jiao B, Hall LL, Green MR et al. 2010 Maternal Rnf12/RLIM is required for imprinted X-chromosome inactivation in mice. Nature 467 977-981. (doi:10.1038/nature09457)

Simpson AJ, Caballero OL, Jungbluth A, Chen YT \& Old LJ 2005 Cancer/testis antigens, gametogenesis and cancer. Nature Reviews. Cancer 5 615-625. (doi:10.1038/nrc1669)

Sin HS \& Namekawa SH 2013 The great escape: active genes on inactive sex chromosomes and their evolutionary implications. Epigenetics 8 887-892. (doi:10.4161/epi.25672)

Sin HS, Barski A, Zhang F, Kartashov AV, Nussenzweig A, Chen J, Andreassen PR \& Namekawa SH 2012a RNF8 regulates active epigenetic modifications and escape gene activation from inactive sex chromosomes in post-meiotic spermatids. Genes and Development 26 2737-2748. (doi:10.1101/gad.202713.112)

Sin HS, Ichijima Y, Koh E, Namiki M \& Namekawa SH $2012 b$ Human postmeiotic sex chromatin and its impact on sex chromosome evolution. Genome Research 22 827-836. (doi:10.1101/gr.135046.111)

Sinclair AH, Berta P, Palmer MS, Hawkins JR, Griffiths BL, Smith MJ, Foster JW, Frischauf AM, Lovell-Badge R \& Goodfellow PN 1990 A gene from the human sex-determining region encodes a protein with homology to a conserved DNA-binding motif. Nature 346 240-244. (doi:10.1038/346240a0)

Skaletsky H, Kuroda-Kawaguchi T, Minx PJ, Cordum HS, Hillier L, Brown LG, Repping S, Pyntikova T, Ali J, Bieri T et al. 2003 The malespecific region of the human $Y$ chromosome is a mosaic of discrete sequence classes. Nature 423 825-837. (doi:10.1038/nature01722)

Slegtenhorst-Eegdeman KE, de Rooij DG, Verhoef-Post M, van de Kant HJ, Bakker CE, Oostra BA, Grootegoed JA \& Themmen AP 1998 Macroorchidism in FMR1 knockout mice is caused by increased Sertoli cell proliferation during testicular development. Endocrinology 139 156-162.

Soh YQS, Alföldi J, Pyntikova T, Brown LG, Graves T, Minx PJ, Fulton RS, Kremitzki C, Koutseva N, Mueller JL et al. 2014 Sequencing the mouse $\mathrm{Y}$ chromosome reveals convergent gene acquisition and amplification on both sex chromosomes. Cell 159 800-813. (doi:10.1016/j.cell.2014. 09.052)

Song R, Ro S, Michaels JD, Park C, McCarrey JR \& Yan W 2009 Many $X$-linked microRNAs escape meiotic sex chromosome inactivation. Nature Genetics 41 488-493. (doi:10.1038/ng.338)

Stouffs K, Tournaye H, Liebaers I \& Lissens W 2009 Male infertility and the involvement of the $\mathrm{X}$ chromosome. Human Reproduction Update $\mathbf{1 5}$ 623-637. (doi:10.1093/humupd/dmp023)

Stouffs K \& Lissens W 2012 X chromosomal mutations and spermatogenic failure. Biochimica et Biophysica Acta 1822 1864-1872. (doi:10.1016/ j.bbadis.2012.05.012)

Suh DS, Styrna J \& Moriwaki K 1989 Effect of Y chromosome and H-2 complex derived from Japanese wild mouse on sperm morphology. Genetical Research 53 17-19. (doi:10.1017/S0016672300027816)

Takano K, Miki T, Katahira J \& Yoneda Y 2007 NXF2 is involved in cytoplasmic mRNA dynamics through interactions with motor proteins. Nucleic Acids Research 35 2513-2521. (doi:10.1093/nar/gkm125)

Toure A, Grigoriev V, Mahadevaiah SK, Rattigan A, Ojarikre OA \& Burgoyne PS 2004a A protein encoded by a member of the multicopy Ssty gene family located on the long arm of the mouse $\mathrm{Y}$ chromosome is expressed during sperm development. Genomics 83 140-147. (doi:10.1016/S0888-7543(03)00216-7)

Toure A, Szot M, Mahadevaiah SK, Rattigan A, Ojarikre OA \& Burgoyne PS $2004 b$ A new deletion of the mouse $Y$ chromosome long arm associated with the loss of Ssty expression, abnormal sperm development and sterility. Genetics 166 901-912. (doi:10.1534/genetics.166.2.901)

Toure A, Clemente EJ, Ellis P, Mahadevaiah SK, Ojarikre OA, Ball PA, Reynard L, Loveland KL, Burgoyne PS \& Affara NA 2005 Identification of 
novel $\mathrm{Y}$ chromosome encoded transcripts by testis transcriptome analysis of mice with deletions of the $\mathrm{Y}$ chromosome long arm. Genome Biology 6 R102.

Tretyakova I, Zolotukhin AS, Tan W, Bear J, Propst F, Ruthel G \& Felber BK 2005 Nuclear export factor family protein participates in cytoplasmic mRNA trafficking. Journal of Biological Chemistry 280 31981-31990. (doi:10.1074/jbc.M502736200)

Turner JM 2007 Meiotic sex chromosome inactivation. Development 134 1823-1831. (doi:10.1242/dev.000018)

Turner JM, Aprelikova O, Xu X, Wang R, Kim S, Chandramouli GV, Barrett JC, Burgoyne PS \& Deng CX 2004 BRCA1, histone H2AX phosphorylation, and male meiotic sex chromosome inactivation. Current Biology 14 2135-2142.

Turner JM, Mahadevaiah SK, Ellis PJ, Mitchell MJ \& Burgoyne PS 2006 Pachytene asynapsis drives meiotic sex chromosome inactivation and leads to substantial postmeiotic repression in spermatids. Developmental Cell 10 521-529. (doi:10.1016/j.devcel.2006.02.009)

Vernet N, Mahadevaiah SK, Ojarikre OA, Longepied G, Prosser HM, Bradley A, Mitchell MJ \& Burgoyne PS 2011 The Y-encoded gene zfy2 acts to remove cells with unpaired chromosomes at the first meiotic metaphase in male mice. Current Biology 21 787-793. (doi:10.1016/j. cub.2011.03.057)

Vernet N, Mahadevaiah SK, Yamauchi Y, Decarpentrie F, Mitchell MJ, Ward MA \& Burgoyne PS 2014 Mouse Y-linked Zfy1 and Zfy2 are expressed during the male-specific interphase between meiosis I and meiosis II and promote the 2nd meiotic division. PLoS Genetics 10 e1004444. (doi:10.1371/journal.pgen.1004444)

Wang PJ, McCarrey JR, Yang F \& Page DC 2001 An abundance of X-linked genes expressed in spermatogonia. Nature Genetics 27 422-426. (doi:10.1038/86927)

Wang RS, Yeh S, Tzeng CR \& Chang C 2009 Androgen receptor roles in spermatogenesis and fertility: lessons from testicular cell-specific androgen receptor knockout mice. Endocrine Reviews 30 119-132. (doi:10.1210/er.2008-0025)

Warburton PE, Giordano J, Cheung F, Gelfand Y \& Benson G 2004 Inverted repeat structure of the human genome: the X-chromosome contains a preponderance of large, highly homologous inverted repeats that contain testes genes. Genome Research 14 1861-1869. (doi:10.1101/ gr.2542904)

Weiss J, Meeks JJ, Hurley L, Raverot G, Frassetto A \& Jameson JL 2003 Sox3 is required for gonadal function, but not sex determination, in males and females. Molecular and Cellular Biology 23 8084-8091. (doi:10.1128/ MCB.23.22.8084-8091.2003)
White JK, Gerdin AK, Karp NA, Ryder E, Buljan M, Bussell JN, Salisbury J, Clare S, Ingham NJ, Podrini C et al. 2013 Genome-wide generation and systematic phenotyping of knockout mice reveals new roles for many genes. Cell 154 452-464. (doi:10.1016/j.cell.2013.06.022)

Xu Q, Lin HY, Yeh SD, Yu IC, Wang RS, Chen YT, Zhang C, Altuwaijri S, Chen LM, Chuang KH et al. 2007 Infertility with defective spermatogenesis and steroidogenesis in male mice lacking androgen receptor in Leydig cells. Endocrine 32 96-106. (doi:10.1007/s12020-007-9015-0)

Yamauchi Y, Riel JM, Stoytcheva Z \& Ward MA 2014 Two Y genes can replace the entire $Y$ chromosome for assisted reproduction in the mouse. Science 343 69-72. (doi:10.1126/science.1242544)

Yang F, Gell K, van der Heijden GW, Eckardt S, Leu NA, Page DC, Benavente R, Her C, Hoog C, McLaughlin KJ et al. 2008 Meiotic failure in male mice lacking an X-linked factor. Genes and Development 22 682-691. (doi:10.1101/gad.1613608)

Yeh S, Tsai MY, Xu Q, Mu XM, Lardy H, Huang KE, Lin H, Yeh SD, Altuwaijri S, Zhou X et al. 2002 Generation and characterization of androgen receptor knockout (ARKO) mice: an in vivo model for the study of androgen functions in selective tissues. PNAS 99 13498-13503. (doi:10.1073/pnas.212474399)

Yu RN, Ito M, Saunders TL, Camper SA \& Jameson JL 1998 Role of Ahch in gonadal development and gametogenesis. Nature Genetics 20 353-357. (doi:10.1038/3822)

Zhang C, Yeh S, Chen YT, Wu CC, Chuang KH, Lin HY, Wang RS, Chang YJ, Mendis-Handagama C, Hu L et al. 2006 Oligozoospermia with normal fertility in male mice lacking the androgen receptor in testis peritubular myoid cells. PNAS 103 17718-17723. (doi:10.1073/pnas. 0608556103)

Zhang YE, Vibranovski MD, Landback P, Marais GA \& Long M 2010 Chromosomal redistribution of male-biased genes in mammalian evolution with two bursts of gene gain on the X chromosome. PLoS Biology 8 e1000494. (doi:10.1371/annotation/ecce3f2a-35e6-4c27-b444-5282489 $82 \mathrm{dbf})$

Zheng K, Yang F \& Wang PJ 2010 Regulation of male fertility by X-linked genes. Journal of Andrology 31 79-85. (doi:10.2164/jandrol.109. 008193)

Received 24 November 2014

First decision 2 January 2015

Revised manuscript received 12 February 2015

Accepted 23 February 2015 